\title{
DOCTRINE OF LEGAL ORDER IN UKRAINIAN AND FOREIGN JURISPRUDENCE: STATUS AND PROSPECTS OF CONVERGENCE LEGAL ORDER AS AN EMPIRICAL STATE OF LEGAL LIFE IN SOCIETY (OR WHATSOEVER)
}

\section{Kryzhanovskii A. F.}

\section{I.INTRODUCTION}

I contemplated a lot on the subject of the scientific category "legal order", which was solidly established in domestic jurisprudence, however for some reason was not developed at all by Western legal scholars in some other countries (mostly post-Soviet). The terms "law" and "legal order" are used as synonyms there, despite the fact that they are not semantically identical. For instance, in German the law - die Recht, the legal order Rechtsordnung, although in some dictionaries it is also translated as "law". Approximately the same situation in the English language: law - rights, legislation, legal order - legal system, which are also used synonymously to denote rights and legislation. Legal reality, for many Western authors, is called either law or legal order, without any difference in the meaning of these words. In this regard the book of the French scientist J.-L. Bergel is indicative, as the author intertwines these categories easily and naturally ${ }^{1}$.

In Ukrainian jurisprudence, the content of law and legal order is filled with different meanings. Law in its most general form is a value-normative system, partly generated and maintained by the authorities, and the legal order is the actual state of public relations, the legal sphere of society, which is formed under the influence of law, is the result of the influence of the law on society. Thus, law is a kind of legislative model, and the legal order is the real, actual (and qualitative) state of the legal life of society. Law reflects due, legal order - matter in the legal sphere.

As a result, I seem to understand one of the reasons for these differences. The law (legal values, precepts, principles) has long been an integral part of the conviction in the Western legal tradition, and its component jurisprudence, that it has rigorously embodied in the phenomena of human and social reality - the behavior of people, the relationship between them. Cases of deviation from law (violation of law, abuse of law) receive the

${ }^{1}$ Бержель Жан-Луи. Общая теория права. Пер. с франц. Г.В. Чуршукова. Под общ. ред. В.И. Даниленко. М.: Nota bene, 2000. 576 с. 
appropriate assessment and reaction of state and public institutions and lead to the restoration and approval of the law.

In the domestic tradition, faith in law has never been strong, not only in broad social, but even in professional and legal discourse. The gap between constitutional declarations and reality was obvious, and could not be filled even by the most powerful ideology of public consciousness and the reason is the many years of experience in an autocratic regime, and especially of the totalitarian Soviet regime. This attitude to law by inertia was also preserved in the minds of Ukrainians, especially since the authorities of an already sovereign state, actually, have done little change to it. As a result, even the appearance of "good" laws did not produce quick results in public practice. Therefore, in modern conditions the distance between the legislative provisions can be seen by «unaided eye «and their real implementation in practice. To illustrate this, it is enough to refer to the practice of compliance with traffic rules, or payment of taxes, corruption and many other things. Though this situation did not appear nowadays. Therefore, even prerevolutionary domestic legal scholars saw reasons for distinguishing between the phenomena of law and legal order.

But the question is quite relevant: is the situation with the observance of laws (and law in general) in other (Western) societies today so prosperous, does the "normative model" of society life contained in the law fully coincide with its real picture? Publication of the work of Harold J. Berman's "Law and Revolution: The Formation of the Western Legal Tradition", "tells about the feeling of crisis in the Western tradition of law, sharpened the perception of problems in the legal sphere. It is obvious that the existence of a legal reality in the life of Western societies, different from the declared current law, requires the understanding of this phenomenon. And the differentiation of law and legal order, theoretical and applied research of these phenomena can become a scientific tool in the system of necessary transformations.

\section{Conceptualization of the legal order within the national doctrine of law}

Domestic jurisprudence postulates the legal order as a qualitative state of legal orderliness of social life. It functions in various spheres of society, manifests itself as a domestic (national), integrative and international legal order. The basic category is the national legal order which is associated with the legal and institutional infrastructure of the state-organized society,

\footnotetext{
${ }^{2}$ Garold J. Berman. Law and Revolution I : The Formation of the Western Legal Tradition. Harvard University Press, 1990. Cambridge, Mass, United States. 672 p.
} 
reflects the historical and social features of its legal development. Therefore, comprehension of the nature of the national legal order, the system of its maintenance is an important task of theoretical and applied jurisprudence. Here it is necessary to admit: transformation of legal ordering of public relations in Ukraine in modern conditions is made without seriously proved scientific developments and predictions.

Maintaining and strengthening the legal order in society in modern conditions render necessitates of the functioning of an extensive law enforcement and human rights mechanism with the involvement of state institutions and civil society. This, in turn, requires a thorough doctrinal support, prediction and planning, determining the strategic goal, the main tasks, forms and methods of activity in this area. Mentioned components are the strands of the phenomenon, which got the word-name "doctrine", with the meaning of an integral, socially recognized system of ideas, goals, provisions, methods and means of achieving and solving problems in a certain area (political, economic, legal doctrine, etc. Legal doctrine is also comprehended as an authoritative scientific study of leading legal theorists and practitioners. As an important element of the legal doctrine, the doctrine of legal order is invoked to life by the social needs of legal order, and is significant both for society in general and for individual citizens, their groups and associations. The doctrine of the legal order is able to acquire an official (para-governmental) status if the relevant state or political institutions record the concepts of maintaining and strengthening the legal order in legal or political acts, programs and other documents. In Soviet times, The official doctrine of law and order was determined by the decisions of party or state bodies without the decisive influence of the scientific community.

The formation of the scientific doctrine of the legal order in Ukraine has its own history, the roots of which go back to the achievements of scientists of the XIX century of the Soviet period and modern times.

A prime example of the pre-Soviet period of development of the theory of legal order is the original concept of L. I. Petrazhitsky. The foundation of this concept was the understanding of law by Petrazhitsky as an idea, a phenomenon of the spiritual world, the individual psyche ${ }^{3}$. He considered the legal order as the result of the effect of a set of laws-tendencies of the legal psyche, and defined it as a solid coordinated system of social behavior

${ }^{3}$ Петражицкий Л. И. Теория права и государства в связи с теорией нравственности. Серия “Мир культуры, истории и философии”. СПб. : Лань, 2000. С. 99-100. 
caused by law $^{4}$. Petrazhitsky sees the concept of legal order through the distinction between intuitive and positive law (two kinds of generic concepts), which are rooted in the human psyche and are imperativeattributive emotions of the individual. Unlike holistic intuitive law, positive law is pluralistic. In order to understand the legal order, it is important that intuitive law is perceived by people as eternal and universal. This gives grounds at the naive legal psyche to see a greater weight of the sensations of intuitive law, which gave rise to positive law, which, according to Petrazhitsky, is determined by the purely psychological characteristics of the perception of these two types of law. Intuitive law does not envisage knowledge by individuals of all the moments that characterize positive normative facts. Moreover, Petrazhitsky argues, people can have rather rough ideas about the law (in a broader sense - about normative facts), they generally may not know them. But this does not prevent them from participate in legal relations. The only possible explanation for this phenomenon is that people have an intuitive right. That is why Petrazhitsky repeatedly emphasized that "intuitive law plays a very significant role as a factor in individual behavior, as well as a variety of large-scale social, economic, political and other phenomena"5. Intuitive and positive laws divide legal reality into three areas: the exclusive dominance of intuitive law, the exclusive dominance of positive law, as well as their dual operation. Each of these areas has a separate meaning for the formation of the legal order. The first one is the most important for the reproduction of the informal legal order, the second area manifests itself in the functioning of the state (official) legal order, and the third form of legal order exists at the intersection of the first and second spheres. The study of the third sphere is very relevant from the standpoint of the dynamics of the legal order and the mutual influence and flow of the official and unofficial legal order. Obviously, further in-depth study of the scientific heritage of L.I. Petrazhitsky and extrapolation of its provisions on the problems of the legal order are able to go beyond the horizons in the theoretical and applied planes. However, there is an issue: should positive law adapt to intuitive law, or should informal law gradually "keep up" to the level of positive law requirements? This concern is very important for maintaining a legal order for which a balance between positive and intuitive law is a necessary condition. As it was pointed out by L.I. Petrazhitsky, "the more the degree of

\footnotetext{
${ }^{4}$ Петражицкий Л. И. Теория права и государства в связи с теорией нравственности. Серия “Мир культуры, истории и философии”. СПб. : Лань, 2000. С. 157-158.

${ }^{5}$ Петражицкий Л. И. Теория права и государства в связи с теорией нравственности. Серия “Мир культуры, истории и философии”. СПб. : Лань, 2000. С. 388.
} 
agreement within these limits at the moment is, the better and more correct, ceteris paribus law operates among the people, the more steady its compliance, in particular, the more there is respect and sympathy to the existing positive law, the more contentment because of the existing social system and the stronger this system is; and vice versa"

B. A. Kistyakovsky is a representative of integrative law understanding. He distinguishes law as a social fact and law as a set of legal norms. Their content does not necessarily coincide, and the legal order existing in life is not identical to the rule of law enshrined in legal norms. Hence his call-to study the legal order existing in life as something independent; this will lead to a socio-scientific study of law or to the study of law as a social phenomenon ${ }^{7}$. According to B. A. Kistyakovsky, law is the only regulatory system that disciplines society ${ }^{8}$. Therefore for him, a disciplined society and a society with a developed legal order are identical. Law is a kind of technology of social life, designed to organize it and embody the ideals of due in the social world. Although the scientist never idealized the possibility of law regarding the establishment of a reasonable, free and fair social order. The stability of the legal order and the democratic regime, according to the scientist, is unthinkable without a high level of legal awareness, political and legal culture of the people, their activity in the fight for the rule of law. In this sense, Russian history contains very few positive examples, and the main blame for the lack of awareness of the value of the rule of law by society is assigned to the intelligentsia by Kistyakovsky. To his mind, the intelligentsia never respected the law, never saw value in it; among all cultural values the law never was for them on first place. The ideal of the legal order for B.A. Kistyakovsky has a personalistic character, and is associated with a legal person. The two sides of this ideal are a person disciplined by law and a stable rule of law, and a person endowed with all the rights that he freely enjoys 9 . Kistyakovsky's idea that "the basis of the rule of law is the freedom of the individual and its inviolability" is still relevant today. Kistyakovsky also emphasizes the value of stability, continuity of the rule of law ${ }^{10}$. The appeal to the scientific heritage of

${ }^{6}$ Петражицкий Л. И. Теория права и государства в связи с теорией нравственности. Серия “Мир культуры, истории и философии”. СПб. : Лань, 2000. С. 394.

Кистяковский Б. А. Право как социальное явление. Социологические исследования.1990. № 3. С. 107.

${ }^{8}$ Кистяковский Б. А. В защиту права (Интеллигенция и правосознание). Вехи: Сборник статей о русской интеллигенции. Вехи. Из глубины. М. : Правда, 1991. С. 122.

9 Кистяковский Б. А. В защиту права (Интеллигенция и правосознание). Вехи: Сборник статей о русской интеллигенции. Вехи. Из глубины. М. : Правда, 1991. С. 115.

${ }^{10}$ Кистяковский Б. А. Непрерывность правового порядка. Юридический вестник. 1917. Кн. XVII. C. 10. 
B.A. Kistyakovsky is also useful in the sense that he is the author of almost the only doctrinal definition of legal order in the literature of that time: it is "a system of relations in which all persons of a certain society have the greatest freedom of activity and self-determination"11.

In General, in the pre-Soviet period, there is a general tendency of the development of domestic legal thought in the promotion of an integrative understanding of the rule of law. At the same time, none of the outstanding lawyers of the heyday of legal thought of this time did not set a goal to create a holistic theory of legal order.

Already at the beginning of the Soviet era, the category of "legal order" due to its "ideological unreliability" is generally removed from the official and doctrinal lexicon. The interpretation of public relations as the basis of law, declared by representatives of Marxist jurisprudence, is explained by the need to justify the Soviet court's activity in accordance with the"revolutionary consciousness and legal consciousness". Legal order is a category that does not fit into the Bolshevik concept. After controversial discussions between Pashukanis and Knocking and Vyshinsky's massacre of these "traitors, enemies of the people, defenders of Trotskyist and Bukharin ideas" the category of order disappeared from the definitions of jurisprudence, and the rule of law - as a legal category "lost its relevance". The category by means of which the qualitative state of "legal" life is determined, for many years has become legality (revolutionary, proletarian, socialist, etc.). At the same time, during the formation of socialist jurisprudence in the first years of Soviet power, the identification of law and order became widespread. The typical one is the definition of law A.L. Malitsky. "Law," he wrote, «is the order of social relations established by the ruling class for the sake of its class interests, which is protected by the organized power of that class. Law, as order, or as the rule of law, manifests itself in certain rules of conduct, is protected by the organized force of the ruling class in the rules of law." Considering the state to be the Creator of law, which guarantees its citizens with rights, Malitsky argues that the "bourgeois" principle is "everything that is not prohibited by law and is considered permissible" and it should be replaced by the principle "only what is allowed by law is possible" $"$.

Legal order as a concept widely used by scientists and practitioners again received registration in the Soviet legal literature only in the mid-60s, to

11 Кистяковский Б. А. В защиту права (Интеллигенция и правосознание). Вехи: Сборник статей о русской интеллигенции. Вехи. Из глубины. М. : Правда, 1991. С. 119.

12 Кистяковский Б. А. В защиту права (Интеллигенция и правосознание). Вехи: Сборник статей о русской интеллигенции. Вехи. Из глубины. М. : Правда, 1991. С. 49. 
some extent, as a reflection of the normative theory of G. Kelsen, but in the form of ideologically oriented, opportunistic constructs. Kelsen's characteristic statism of understanding law and order (law - compulsory normative order of human behavior) paradoxically proved acceptable to the Soviet official legal doctrine, and until a certain time existed in all spheres of domestic jurisprudence. The understanding of law as a system of obligatory norms and prescriptions of state power somehow forms the statist model of law and order, according to which it is interpreted as the order of social relations regulated by the norms of law, established in compliance with the requirements of legality. If, however, the rule of law is understood primarily as a regime that characterizes the relationship between the state apparatus and the citizen, it is obvious that in this model of law and order, the role of the main force that establishes and ensures the rule of law is assigned exclusively to the state. For the one lastr, the citizen is only an object of power activity. In the framework of the statist paradigm the semantic field of the category of the rule of law traditionally considered in connection with the legality, mainly as a derivative of law, and therefore, in fact, is in the shadow of the law. Often, even in thorough scientific works, the phrasestamp "law and order" reflects just such a non-independent, secondary doctrinal, and, therefore, the practical status of law and order.

The perception of law as a consequence, the result of law not only distorts the understanding of the social aspects and values of legal ordering of social life, inappropriately exaggerates the significance of law in the ratio of the categories "law and order", but also spreading statism on the level of legal phenomena, vital for society as a whole, underestimates the scale of the importance of the rule of law as a social and personality legal values. It impoverishes the understanding of legal reality as beyond its perception remain a social base, the characteristics of law as a socio-legal phenomenon, the existence of which is correlated by the influence of the entire social system of control of public relations and ensuring the integrity of the society.

If to understand Statism in terms of law and order it leads to the fact that the subject of the formation of law and order (the state) is somehow opposed to its carriers-society and the citizen. This has significant practical implications. That is why the assessment of the rule of law is carried out on the basis of its comparison with offenses and crime, that is, only one of the many manifestations of legal deformation. A very different picture is formed if the rule of law is opposed to the disorder and destruction of law: this opens the possibility of penetrating into the underlying formation of conditions that form and destroy the rule of law. And the task of ensuring law and order becomes possible to formulate not in a negative sense (fighting crime, stopping offenses, etc.), but as a program of positive, 
socially oriented actions and means that have a reliable legal basis. Inherited from the Soviet era, "linear" ideas about the rule of law as a result of socialist legality, that is, the consequence of "strict and rigorous execution by state bodies, officials, public organizations and citizens of laws and regulations" in modern conditions of de-ideologize of legal sphere has largely lost its public appeal and effectiveness. However, with the inertia inherent in the doctrinal sphere, these ideas retain their existence in theoretical, applied, and especially in practical jurisprudence, or acquire new outlines. "The rule of law, - Yu.N. Oborotov emphasizes, - stands as the semantic purpose of law, which is achieved by ensuring the stability of human existence. However, often in the system of legal values the defining place is given to freedom and justice, while the rule of law is considered as the "lowest in rank" in the hierarchy of values of law and is even characterized as an additional value"13. To a large extent, the doctrinal and applied images of law and order in Ukrainian jurisprudence now retain postSoviet characteristics, against which the beginnings of its new vision grow.

Therefore, the way out of this situation is not only in overcoming the statist paradigm of understanding and formation of the rule of law, but also in moving to another level of its perception, first of all, in comparing the rule of law with the legal categories of meta- and mega-levels (law, legal reality, legal life, legal culture, etc.). This level sets the change of methodological vectors of development of law and order, appeal to those developments of modern jurisprudence, which open new horizons of its comprehending. At the same time, it significantly expands the perception of the whole picture of legal life.

The state of legal spheres of modern society requires a rethinking of the whole complex of theoretical applied problems concerning the nature of law, the role and importance of civil society and the state in its provision, identifying the whole system of factors and conditions that affect the condition of the rule of law and tendencies of its development. Such factors include worldwide - globalization, environmental and energy problems, terrorism and organized crime, the "information revolution", the transformation of public consciousness, called postmodern, as well as internal - the level of political stability, economic and foreign policy, the effectiveness and social orientation of public administration, the quality of functioning of law-protecting institutions of the state and civil society.

\footnotetext{
${ }^{13}$ Оборотов Ю. Н. Аксионормативные начала правопорядка. Сучасний правопорядок: національний, інтегративний та міжнародний виміри: Тези Міжнародної науковопрактичної конференції. О.: Фенікс, 2008. С. 6.
} 
The range of problems that are waiting for their resolution by legal theorists, representatives of industry and applied jurisprudence, covers the concept and structure of the rule of law, the basic (key) principles on the basis of which its ideal model should be built. It is necessary to develop criteria allowing giving an objective assessment of the real state of the legal order in different spheres of public life, means and methods of its strengthening in the conditions of ongoing transformations, complication of the socio-political and economic situation, etc. All this brings the problem of law and order in the plane of the need for its systematic awareness, rethinking on the basis of modern, adequate to the nature of modern law and order, methodological approaches.

The theoretical component of modern systemic vision of the rule of law requires understanding the contexts available in the law basic concepts of law to disclose the correlation of law and right, law and order and public order, rule of law, legitimate and law-violating behavior, legal relationships, etc. Extrapolation of the problems of law and order or some type of legal thinking in a certain way highlights the role of the state and civil society in the formation of the rule of law, principles, forms and methods of its provision.

It should be admitted that in the modern Ukrainian jurisprudence, new views on the rule of law are approved, which create a certain scientific basis for the development of the modern domestic doctrine of the legal order. The characterizing the doctrinal perception of the legal order defining moment is the presence of solidarity of the scientific community in the understanding of the high importance of the legal order in the system of legal categories, which is rightly noted by N. N. Onishchenko, along with others (public order, legality, social security, etc.) is key in legal science and law enforcement practice ${ }^{14}$. This gives grounds to consider the legal order in accordance with the approach declared by A. M. Vasilyev ${ }^{15}$, in the most extended content-semantic range of categories of the theory of law. It is very symbolic that N.I. Kozyubra focused his vision of the rule of law on its comparison with the rule of $\operatorname{law}^{16}$ : this methodological section opens a

${ }^{14}$ Оніщенко Н. М. Категорія правопорядок: сутнісні виміри, підходи та розуміння. Сучасний правопорядок: національний, інтегративний та міжнародний виміри: Тези Міжнародної науково-практичної конференції. О.: Фенікс, 2008. С. 63.

15 Васильев А. М. Правовые категории. Методологические аспекты разработки системы категорий теории права. М., 1976.

16 Козюбра М. I. Додержання вимог принципу верховенства права як умова забезпечення правопорядку. Сучасний правопорядок: наиіональний, інтегративний та міжнародний виміри: Тези Міжнародної науково-практичної конферениії. О.: Фенікс, 2008. C. 58. 
powerful synergistic potential of interaction between these basic legal phenomena, the possibility of mastering other legal phenomena. Undoubtedly, the rule of law, as a fundamental legal value, implicitly contains a system of values of the legal order. Among them Yu.N. Oborotov refers to as the principles of humanism (humanity), legitimacy (recognition), legality (formality), justice (conformity of action and retribution), procedural (procedure), tolerance( tolerance), hierarchy (subordination), situativeness (discretion) $)^{17}$. N.I. Kozyubra speaks about the principles of decisive importance of natural, inalienable and inalienable human rights and freedoms in relations with the authorities, the separation of powers, the supremacy of the Constitution, the principles of certainty, proportionality, legal security and protection of trust, as well as the independence of the court and judges ${ }^{18}$. The rule of law means legality, based on the recognition of unconditional acceptance of the Supreme value of human, his protection from the arbitrariness of power institutions and their officials. Therefore, "... the requirement of legality in accordance with the rule of law applies only to the activities of public authorities and their officials, and not to citizens. Quite often this requirement is referred to as the legitimacy of governance. According to it, no act of government can substitute its regulation for the law, and any action or authority of the governing body must have its basis in the law, that is, comply with the principle "what is not expressly permitted by law, is prohibited"19. Following this approach, it is necessary to distinguish the achieved legal order in the activities of state institutions as one that is formed on the basis of legality. This legal order, on the one hand, is a relatively independent sphere of legal life of society, and the other - an important factor of legal order in other areas (economic, industrial, social, political, ideological, etc.). From this arises the possibility of analyzing the role of state institutions and civil society institutions in ensuring the legal order in society, and the reflection of these provisions in the doctrine of the legal order.

Methodologically important for the development of the modern doctrine of the legal order is the need approach to law (scientific school of

${ }^{17}$ Оборотов Ю. Н. Аксионормативные начала правопорядка. Сучасний правопорядок: національний, інтегративний та міжнародний виміри: Тези Міжнародної науковопрактичної конференції. О.: Фенікс, 2008. С. 6.

${ }^{18}$ Козюбра М. І. Принципи верховенства права і правової держави : єдність основних вимог. Наукові записки Національного університету "Києво-Могилянська академія". Юридичні науки. 2007. Т. 64. С. 3-7.

${ }^{19}$ Козюбра М. І. Принципи верховенства права і правової держави : єдність основних вимог. Наукові записки Національного університету “Києво-Могилянська академія". Юридичні науки. 2007. Т. 64. С. 59. 
P.M. Rabinovich). This approach opens the possibility of mastering the legal order as a value inherent not only in the social being of man, but also as a human - biological being. The needs of a safe existence, a sense of security from external dangers have been and remain a powerful mover of human social activity, the formation of an extensive "infrastructure" of the ordering and safety of their lives. As P.M. Rabinovich observes, it is the "need" reasons are often more effective than other circumstances ${ }^{20}$. Therefore, the potential of the need-based approach based on anthropocentric principles should also be reflected in the doctrine of the modern legal order.

A vivid example of a doctrinal breakthrough in the search for the theoretical basis of the modern legal order is the idea of A.N. Kostenko and his followers. Naturalistic jurisprudence, based on the theory of social naturalism, offers the position that "the rule of law is a state that is formed in the implementation of existing legislation, in which the laws of "natural law" are embodied"21. Very valuable for the understanding of the modern legal order should be recognized not just the proclamation of the unity of legal culture and positive law, but also the emphasis that the legal culture of citizens is understood as a measure of coordination of their will and consciousness with the laws of natural law. Therefore, «in the activities ensuring law and order, - A.N. Kostenko says, - it is necessary to be guided by the rule: culture is the mother of order" ${ }^{\prime 2}$.

The legal order, without exaggeration - is an important dimension, an independent and objectively necessary hypostasis of the existence of law. Without its embodiment in law-meaningful (first of all, lawful) behavior, legal relations, which according to the laws of "Brownian motion" are formed into a system of orderly legal life, law would remain a great idea, a system of perfect texts, principles, norms and regulations. The rule of law O.F. Skakun indicates, - is the superlative, (end result) of the right and necessary condition for the functioning of a social system ${ }^{23}$. The state and quality of the legal order give real ideas about the state of the "legal health" of society, the legal security of citizens (and sometimes of the whole society), as well as about the legal culture of society and its components.

\footnotetext{
${ }^{20}$ Рабінович П. Сутність право розуміння. Право Украӥни. 2008. № 9. С. 6.

${ }^{21}$ Костенко А. Н. Теория “натуралистической” юриспруденции - основа нового правопорядка. Сучасний правопорядок: національний, інтегративний та міжнародний виміри: Тези Міжнародної науково-практичної конферениї. О.: Фенікс. 2008. С. 14.

${ }^{22}$ Костенко А. Н. Теория “натуралистической” юриспруденции - основа нового правопорядка. Сучасний правопорядок: начіональний, інтегративний та міжнародний виміри: Тези Міжнародної науково-практичної конферениї. О.: Фенікс. 2008. С. 14.

${ }^{23}$ Скакун О. Ф. Теорія держави і права (Енциклопедичний курс) : підручник. Х. : Еспада, 2006. С.730.
} 
Therefore, the legal order is perceived as a favorable state (environment) of the legal sphere, which the life of individuals, public entities and society is in. Here the remark of O.F. Skakun is very fair: the legal order as dynamic system incorporates all ordering bases of legal character ${ }^{24}$. It should be added that the legal order is the result of a whole complex of social and legal factors and conditions that, acting in conjunction or in "competition", create a certain configuration of the legal order, provide a certain state of it, and therefore its real characteristics depend not only on law and other legal means, but also on a wider range of them-social, political, economic, etc. Therefore, the doctrine of the legal order should be based on the positions developed by science, in accordance with which the doctrinal image can be formed and the modern legal order can be proclaimed as a concept that can be effective in the practice of legal ordering of modern society.

The assertion of the idea of law as a measure of freedom, justice and formal equality in the public consciousness has a powerful potential in creating the doctrine of the modern legal order. No less important is the understanding of the carriers of professional and competent consciousness of pluralism sources of modern law and legal order, the importance primarily of those that derive their origin from natural law, recognized by the civilized world standards of human rights and freedoms. Normative sources of legal order (principles of law, normative legal acts, precedents, legal values and traditions, doctrine) are equal in the legal regulation of public relations, and the law is recognized as a source of legal order on condition that it is a rights law.

The modern legal order is intended to be a legitimate order in the legal sphere, that is, the actual (actually existing) state of order of the legal life of society, which is maintained by the dominant part of society, primarily by civil society, for which it is necessary and most valuable. The legitimacy of the legal order is determined by its compliance with the interests and needs of civil society, which is in solidarity with the existing legal order, and by its will and efforts contributes to its establishment and sustainable functioning. The legitimacy of the legal order informs it not of the state, but of the social nature. Therefore, the modern legal order is a civil legal order, because its image, standards and support come from civil society, are transmitted to the state, and are carried out under the control of civil society. Such a legal order is formed, first of all, by the daily self-organization of civil society and is supported by an extensive system of its institutions, and, therefore, not only does not limit the freedom of the individual, but also contributes to the disclosure of its creative potential.

\footnotetext{
${ }^{24}$ Скакун О. Ф. Теорія держави і права (Енциклопедичний курс) : підручник. Х. : Еспада, 2006. С. 669.
} 
The nowadays legal order is conceived as a legal order in the legal sphere, which, thanks to social consciousness and civil society institutions (primarily independent and unbiased media) is reproduced and developed as a state of explicit, transparent legal existence. The adequacy of the perception of the legal order by society is not deformed by ideological clichés and official myths. Latent legal processes, illegal quasi-legal practices and other deviations from the modern legal order receive reliable, first of all, doctrinal and professional legal expert assessment and are subject to rational influences of the relevant institutions of the state and civil society.

The modern legal order also needs such quality as its economic expediency, the ability to be a kind of "legal capital" in the economic sphere of public life, a legal environment that promotes the activation of entrepreneurial activity, attracting investment. Such characteristic of the modern legal order as its maintenance within reasonable (optimum) material and financial costs for society, that is unencumbered for the state budget is also important.

The modern legal order is a morally justified and religiously verified order in the legal sphere. This trait of it characterizes the fact that the moral and religious foundations provide its reliability and stability, as well as additional legitimation.

The modern legal order should be provided with a necessary, sufficient (but not excessive), highly organized, operating on a legal and professional basis, effective system of specialized law enforcement institutions. Rational, consistently scientific solution of this problem in the framework of the doctrine of legal order should be based on a clear definition of the role and place of state institutions in this area so that these activities, on the one hand, was extra to self-organization society, and with another - will likely be necessary and effective. And most importantly, to the state power with its institutions without any exception to act in the framework of legal legitimacy, and to support with its efforts the state of legal order in society.

\section{CONCLUSIONS}

The legal order in the today's era appears as a polystructural, multi-level phenomenon, the legal nature of which reflects the dominant tendencies to deepen the diversity of legal existence. Therefore, the doctrine of the contemporary legal order must take into account the diversity of legal orders in modern society, to cover all-both large-scale and the smallest elements of the legal ordering of social life. The multiplicity of legal orders determines the need to choose effective means of ensuring the legal order in different spheres of society. 
The legal order is a "companion", a factor and a condition of civilized life of people, and by virtue of the social and spatial existence of the person himself arises and is established where his social activity takes place. The "primary carrier" of the legal order is the individual. Each subject of law by his daily behavior "creates" the legal order, affects the "General legal picture" in public places, at work, in the village, city, etc. It is on the basis that the subject of the creation of order is first an individual and then a variety of associations of people - legal entities, bodies, organizations, etc. - jurists distinguish between individual and collective law and order ${ }^{25}$. These classes of legal orders in theoretical discourse can be methodologically significant categories for understanding the "atomicity" and complex structuring of the legal order precisely from the point of view of the role of man in its formation. In the practical sense, this means the need to shift the emphasis in the formation of the legal order in the plane of maximum involvement of the personal legal potential of each individual (legal person).

The legal order is always connected with a certain human community and the sovereign power legalized in it, which exist in a certain territorial space within the recognized state borders. The legal order is territorially formed as identical to the territorial configuration of society and the state-in a certain way the existing areas of human activity. Since each state within its borders seeks to provide its own means and methods of a certain legal order, (and this differs from the legal structure of other countries), so it is this order, which arises and operates within a separate sovereign state, and can be defined as a category of Genesis for the development of legal doctrine. This legal order can be conditionally called the national legal order.

National legal order, as a basic category in the characteristics of the plurality of legal order, is the basis of many institutional entities that are produced by society and its power institutions to ensure the legal order in the life of society. Therefore, as part of the national law and order, there are grounds to see such elements as localized (law and order that is in established institutionalized human collectives), local (village, city, district) and regional (region, province, district, etc.) legal orders. These grounds are connected with the fact that people mediate their life activity in the territorial organizations of villages, cities, regions, on the "territorial-human" expanses of which the legal order of life is formed. Actually, each person "feels", i.e., perceives the rule of law at the level

\footnotetext{
${ }^{25}$ Общая теория права : пер. с франц. Под общ. ред. В. И. Даниленко. М. : NOTA BENE, 2000. C. 332.
} 
of events of everyday life, the immediate environment, as a system of factors that have direct contact with his needs and interests, security, etc. Labor, educational or social activity of a person is mediated in the respective collectives, where a certain state (atmosphere, environment) of the legal order is also formed. This order is characterized by corporatism, it is formed within communities that perform certain social functions and are regulated by a special system of legal regulations. Such laws are called specialized in contrast to the General, devoid of such specificity. The separation of the components of the national legal order is not only doctrinal, but also practical because the national legal order, which is perceived as a whole, is actually quite vague. It consists of different, unequal in quantitative and qualitative characteristics of law and order, which differ significantly from each other. It is no secret that the state and level of legal order in different cities and regions of Ukraine have significant differences. Therefore, the doctrine of the modern legal order should take into account the nature of these differences, and provide for the use of effective means to overcome negative imbalances.

The current state of the doctrine of the legal order in Ukraine reflects both the General situation in the legal sphere of public life, and in doctrinal theoretical and applied jurisprudence, in particular. The need for large-scale transformations in the field of establishing the rule of law in Ukraine, reforming the state apparatus, combating corruption, forms a public demand for modern innovative solutions to these problems as components of strengthening the modern legal order. The phenomenon of legal order here appears in two hypostases - as a doctrinal context, a theoretical model of legal ordering of social life, and as a result of the entire process of legal development of society.

\section{SUMMARY}

Discussion by the scientific community of the fundamental problems of legal development of Ukrainian society, in our opinion, will create the necessary prerequisites for the development of a modern doctrine of the legal order and the successful solution of practical problems in the field of its maintenance. Attracting the attention of foreign scientists to the problems of distinguishing law and legal order will allow to hold a discussion on a set of issues leading to the convergence of legal doctrines.

\section{REFERENCES}

1. Бержель Жан-Луи. Общая теория права / пер. с франц. Г. В. Чуршукова : под общ. ред. В. И. Даниленко. М.: Nota bene, 2000. $576 \mathrm{c}$. 
2. Васильев А. М. Правовые категории. Методологические аспекты разработки системы категорий теории права. М., 1976. 264 с.

3. Garold J. Berman. Law and Revolution I : The Formation of the Western Legal Tradition. Harvard University Press, 1990. Cambridge, Mass, United States. 672 p.

4. Кистяковский Б. А. Право как социальное явление. Соичилогические исследования. 1990. № 3. С. 99-109.

5. Кистяковский Б. А. В защиту права (Интеллигенция и правосознание). Вехи: Сборник статей о русской интеллигенции. Вехи. Из глубины. М. : Правда, 1991. С. 122-149.

6. Кистяковский Б. А. Социальные науки и право. М.: Издание М. и С. Сабашниковых, 1916. 718 с.

7. Кистяковский Б.А. Непрерывность правового порядка. Юридический вестник. 1917. Кн. XVII. С. 7-10.

8. Козюбра М.I. Принципи верховенства права і правової держави : єдність основних вимог. Наукові записки Національного університету “Києво-Могилянська академія”. Юридичні науки. 2007. Том 64. С. 3-7.

9. Козюбра М.I. Додержання вимог принципу верховенства права як умова забезпечення правопорядку. Сучасний правопорядок: національний, інтегративний та міжнародний виміри: Тези Міжнародної науково-практичної конференції. О.: Фенікс, 2008. C. 58-62.

10. Костенко А.Н. Теория “натуралистической” юриспруденции основа нового правопорядка. Сучасний правопорядок: наиіональний, інтегративний та міжнародний виміри: Тези Міжнародної науковопрактичної конферениї̈. О.: Фенікс, 2008. С. 12-15.

11. Малицкий А. Советская конституция. Харьков, 1924. 188 с.

12. Оборотов Ю. Н. Аксионормативные начала правопорядка. Сучасний правопорядок: національний, інтегративний та міжнародний виміри: Тези Міжнародної науково-практичної конференції. О.: Фенікс, 2008. С. 5-7.

13. Оніщенко Н.М. Категорія правопорядок: сутнісні виміри, підходи та розуміння. Сучасний правопорядок: наиіональний, інтегративний та міжнародний виміри: Тези Міжнародної науковопрактичної конференщії. О.: Фенікс, 2008. С. 63-65.

14. Петражицкий Л. И. Теория права и государства в связи с теорией нравственности. Серия “Мир культуры, истории и философии”. СПб. : Лань, 2000. 608 с.

15. Рабінович П. Сутність праворозуміння. Право України. 2007. № 9. C. 3-7. 
16. Селіванов А.О. Проблемні аспекти законотворчого процесу та їх відображення в рішеннях Конституційного Суду України. Право України. 2004. № 9. С. 34-36.

17. Скакун О. Ф. Теорія держави i права (енциклопедичний курс) : підручник. Х. : Еспада, 2006. 840 с.

Information about the author: Kryzhanovskii A. F.,

Great Doctor of Law, Professor, Head of the Department of State and Legal Disciplines, International Humanitarian University 33, Fontanska Road str., Odessa, 65009, Ukraine 